\title{
No Problem Detected
}

National Cancer Institute

\section{Source}

National Cancer Institute. No Problem Detected. NCI Thesaurus. Code C91894.

The device complaint or problem cannot be confirmed. 